\title{
MOTIVES AND BARRIERS TO THE CONSUMPTION OF INNOVATIVE FOOD PRODUCTS BY POLISH AND UKRAINIAN CONSUMERS
}

\section{Anna Jasiulewicz, Marzena Lemanowicz}

(1) Warsaw University of Life Sciences, Faculty of Economic Sciences, Warsaw, Poland

(2) Warsaw University of Life Sciences, Faculty of Economic Sciences, Warsaw, Poland

\author{
Anna Jasiulewicz \\ Warsaw University of Life Sciences, \\ Faculty of Economic Sciences, Warsaw, Poland \\ annajasiulewicz@gmail.com \\ Article info \\ Paper category: Preliminary paper \\ Received: 16.10.2016. \\ Accepted: 28.11.2016. \\ JEL classification: D11, Q13
}




\begin{abstract}
The significant increase in the number of new food products means consumers have the opportunity to choose from among a wide range of innovative foods, which bring a variety of benefits to consumption, but can also, for some, raise uncertainty, opposition and suspicion. The article reviews the literature on innovative food products and their acceptance by consumers. The results of own research on the purchase motives and barriers to consumption of such products are presented in the context of theoretical considerations. The study is presented in relation to the issue of consumer innovativeness as a determinant affecting the approval or rejection of new products. The respondents' degree of innovativeness was evaluated according to Rogers' concept and the impact of this variable on the respondents motives of to purchase innovative products. For the comparative analysis of Polish and Ukrainian consumers' behaviour on the innovative food products market, international research was conducted in 2015 on a sample of 340 Polish and 255 Ukrainian respondents $(595$ respondents in total). The results clearly show consumer types differing from the Rogers distribution, as well as differences between Polish and Ukrainian consumers' appetite for innovation. Analysis of the literature and the research results together indicate that the motives and barriers to consuming innovative food products come down to features of the innovation (including price, functionality, healthiness, convenient packaging, taste), consumer characteristics (neophilia, neophobia, innovativeness) and environmental characteristics (trends in consumption, marketing and social communication). Those consumers who are innovators play an important role in shaping the positive attitudes of buyers in relation to innovative food products. Products possessing attributes consumers consider to be essential may also help in the desire to adopt innovation. Basing on the research results certain implications for managers responsible for introducing new food products to the market were presented in the paper.
\end{abstract}

\title{
Keywords:
}

innovations; innovativeness; consumer; motives; barriers 


\section{INTRODUCTION}

Consumer adoption of innovative food products has been studied across a number of scientific disciplines. Differences can be seen in the analyses at the macroeconomic level, where the focus is on the costs and benefits of disseminating innovation, and on the microeconomic level, where the focus is on the individual, his attitude, and the motivations and barriers to purchasing innovation (Ronteltap et al., 2007).

Today's consumers enjoy a wide assortment of foods that possess innovative qualities and are beneficial to consume. However, consumers view some innovation with disapproval and suspicion. Companies bringing innovative products to the market face neophobia, which is an unjustified fear, fear of the unknown or anything new, and is pronounced where food products are concerned. Neophobia affects above all food products and foodstuffs classified as innovative (Earle et al., 2007). Food neophobia can be defined as the "phenomenon of avoiding new, unknown foods" (Pliner and Hobden, 1992).

It seems that consumers who possess the qualities of innovators in their social groups play an important role in overcoming neophobia. As people who command a thorough understanding of innovation in the market and a willingness to communicate, innovators influence the formation of consumer attitudes towards other new and innovative food products. Equipping innovative products with attributes essential for acceptance by consumers can help in their adaption. Such attributes can be market-related-functional or organic foods-or not, such as complexity or the opportunity to try innovation.

To achieve the aims of our research, the following definition of innovative food products was included in the questionnaire: a new food product that has never been offered on the market or an enriched and improved version of a product that does already exist on the market (one with modified ingredients or packaging, for instance easy to prepare, consume and store); being beneficial for one's health, physical condition or intellect; a genetically modified product (gmo); an ethnic product known only to a certain group of people; an organic product. The definition applies to groups of products proposed as innovative foods by Tourilla et al (2001). No food products have been enumerated or presented to the respondents as examples or as a particular object of study. 


\section{THE AIM, MATERIALS AND METHODOLOGY}

The aim of the article is to present issues concerning the motives and barriers to consuming innovative food products by Polish and Ukrainian consumers.

The literature on consumer behaviour on the innovative foods market was used to inform the writing of the article. In the context of the theoretical considerations, selected results of our own international, survey-based research were presented, comparing the behaviours of Polish and Ukrainian consumers on the innovative food products market. The research was conducted in 2015 on a sample of 34,0 Polish and 255 Ukrainian respondents ( 595 respondents in total). The survey in Poland was conducted using an online survey while the one in Ukraine was done with an auditorium survey. The results are not representative, and should be interpreted with a dose of caution, as they express the opinions only of those individuals who wished to take part in the research. Nonetheless, some differences in the behaviors of the two groups are statistically significant.

\section{THE MOTIVES AND BARRIERS TO CONSUMING INNOVATIVE PRODUCTS IN THE LIGHT OF THE SUBJECT LITERATURE}

Numerous aspects determine the adaption of new products on the food market, including the characteristics of the innovation itself, consumer characteristics, environmental characteristics (eg. the social system), and social communication and marketing (Figure 1.). In addition to objective factors at work, there are also subjective ones reflecting the perception of different facts by consumers (JeżewskaZychowicz, 2012). All of these aspects can function as barriers to the consumption of innovation, or encourage consumers to try it. 
Figure 1.: Conditions of acceptance of innovative food products by consumers

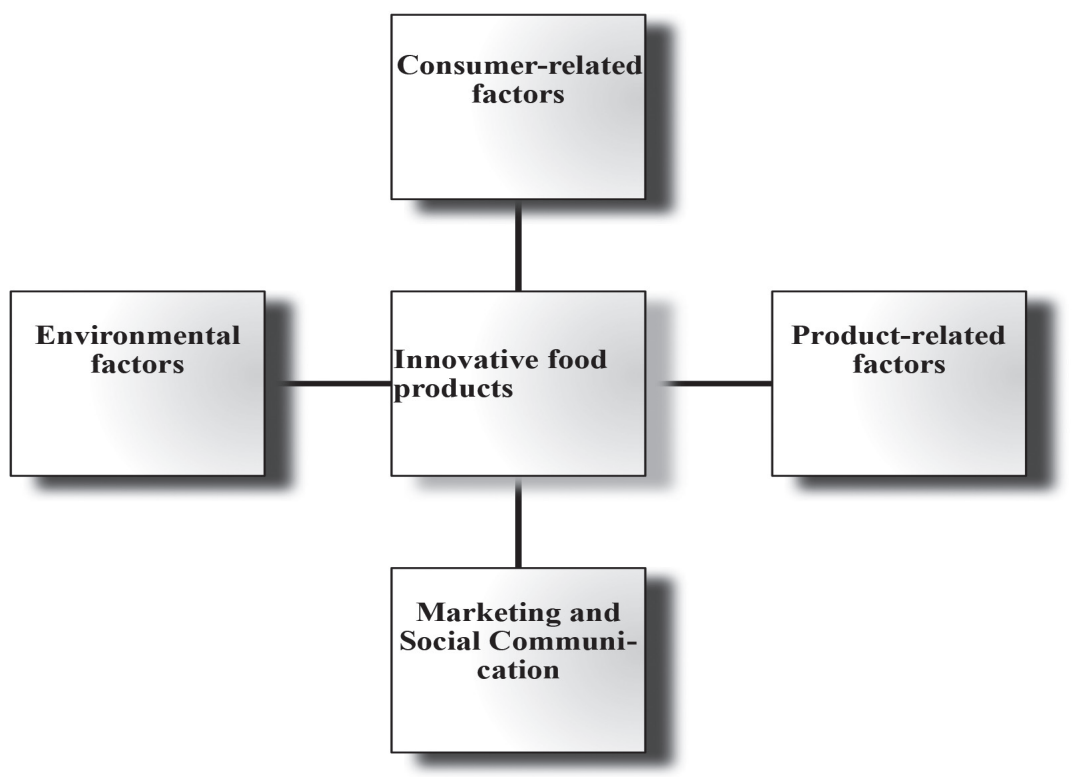

Source: the authors' studies and synthesis based on Marzena Jeżewska-Zychowicz, (2012)

The reactions of consumers to new foods can be conditioned to a large degree by their demographic, psychological and social charactertistics, as well as their economic status. Labay and Kinear (1981) have observed that education, age, phase of life, professional activity and income influence one's acceptance of new food products. Additionally, innovate products can stimulate in some a desire to become familiar with them. while others feel no such need. This is determined by the tendency to adapt and human curiosity (Jeżewska-Zychowicz, 2007). The purchaser seeks primarily to experience pleasure and positive emotions, and to avoid negative ones. Maximum willingness forms when there is little or no fear. Arts et al. (2011) state that consumers tend more frequently to adopt those innovations which are more complex, and better suited to their needs, thus reducing the uncertainty they perceive. Some consumers are by nature fearful, and therefore their level of openness to innovative products is very low. Differences between consumers resulting from the stimulation or susceptibility to fear condition their reactions to new products (Jeżewska-Zychowicz, 2014).

The characteristics of innovative products to a large degree determine whether consumers have a positive or negative attitude to them. Packaging, price, taste, and general appearance have been considered in research on the adoption of innovative food products (Lowe and Alpert, 2015). Today's consumers assess products on the basis of their health and nutritional qualities. From a wide variety of products, buyers ever more 
often choose those which do not contain chemical preservatives and artificial colours, but are rich in vitamins, fibre, and minerals, and low in fat and sugars (Górska-Warsewicz, 2003). Price can also be an essential factor in the decision to purchase a product. Higher prices tend to reduce consumer purchasing (Laskowski and Górska-Warsewicz, 2014).

Environmental factors such as consumption trends also figure into the acceptance of innovation. Changes occurring in consumer behaviour are often a result of and causative factor in the appearance of certain trends. Many consumers pay attention to the health and environmental apects of food. Choosing to eat high-quality foods is more and more often becoming a lifestyle choice, and leading consumers to look for new types of food that meet their expectations (Adamowicz, 2008). Finally, formal and informal marketing and social communication also influence consumer decisions (Kraszewska, 2011).

\section{CONSUMER INNOVATIVENESS}

Numerous authors believe that the acceptance or rejection of innovation depends to a large degree on consumer characteristics, including the degree of their innovativeness (Goldsmith and Hofacker, 1991). According to Goldsmith (2001), the term „consumer innovativeness" describes buyers who have a need to discover new products on the market and own them. They possess knowledge about innovative products, are not overly price sensitive and are frequent users of such goods.

According to Everett Rogers, who penned the theory of the diffusion of innovation, the individual innovativeness is the degree to which a given individual adopts innovation earlier than other individuals in a system. The consumer who adopts innovative products sooner than others is perceived as more innovative. Rogers divided consumers into five groups according to how quickly they adopted innovation, with consideration of the characteristics of each group and their role in diffusing innovation in society. Rogers' five groups, which other researchers have also described, include: Innovators, Early Adopters, the Early Majority, the Late Majority, and Laggards.

The innovators are, at 2,5\% of society (according to Rogers), the mavericks. They do not feel close ties to society, and it is they who bring innovations to the market. Whether innovation exists on the market depends upon them. They have a talent for advanced technology, seek challenges and do not fear the risk in purchasing products. They like to demonstrate their originality and progressiveness, and command high economic and social status. They are often disloyal consumers, being fascinated with new products only briefly then quickly losing interest as newer, more attractive ones appear.

Comprising $13,5 \%$ of society, the early adopters are open to new products and are regarded as successful. Their opinions are the vanguard; they are respected and often followed, so they are essential in diffusing innovation, because given their rela- 
tively high numbers and network of connections in their respective groups, they help speed up the diffusion process. They are educated and other groups of consumers treat them as well-informed experts. Foxall i Bhate (1993) observe that early adopters buy more innovative food products than do innovators probably, they maintain, because they are more involved in a consistent pattern of healthy consumption, so one would expect them to actively seek innovative food products with 'health food' attributes, which is to say organic and functional foods. According to researchers, the greatest number of 'food neophiles' - those consumers who prefer above all unknown food products and actively seek new types of products - will be found among the early adopters.

Comprising 34, percent of society, the early majority are cautious individuals who carefully weigh their every purchase. They have numerous connections to the system and are involved. According to Klincewicz (2011), they are pragmatists and „not interested in products that do not have „reference purchasers”. For them, only time can determine if a product is worth purchasing.

Also accounting for 34, percent of society by Rogers' calculations, the later majority are extremely cautious and sceptical of new products. Their decision to adopt a product is often tied to its economic benefit and pressure from others.

Finally, at 16 percent of society, the laggards are traditional, suspicious, isolated and don't like change. They have limited financial means, avoid risk and fear wasting money. To decide to purchase a new product, they need concrete arguments convincing them it is the right purchase. The laggards have a high „,innovation threshold", which means that a lot of consumers must be using a new product (eg eating a new food) before they will adopt it too.

Steenkamp et al. (1999) also note that high consumer innovation is a function of being independent, extroverted and impulsive, while Foxall and Bhate (1993) maintain that innovation also suggests a sense of self-worth, open-mindedness and tolerance for ambiguity.

\section{RESEARCH RESULTS}

Empirical research intended to investigate consumer innovation with a particular focus on identifying the motives and barriers to buying innovative foods was done in Poland and Ukraine. The research sample included 595 respondents $-34,0$ Poland and 255 Ukrainians. 411 were women (24,6 Polish and ${ }_{16} 6$ Ukrainian) and 184 men (94 and 90, respectively). The ages varied, though 81 percent of the Ukrainian sample was largely made up of young people up to the age of 25 . Nearly 4.8 percent of the Polish sample were 25 or younger, 40 percent were $25^{-39}$ and 12 percent were older than 40 . A large majority of the sample was single (80 percent of Ukrainians and 69,5 percent of the Poles) and had not finished their university degree ( 74 and $5^{3}$ percent). 60 of the Ukrainians $(23,5$ percent) and 14,4 Poles ( 4,2 percent) indicated 
they held a university degree. Most of the sample belonged to three- or four-member households (74 and 52 percent, respectively).

The most Polish and Ukrainian respondents (41 percent) reported monthly income around the minimum wage. 27 percent of Ukrainian and 22 percent of Polish respondents reported income per person in the household amounting to twice the minimum wage while 15 and 25 percent of respondents reported income below the minimum wage. The Polish and Ukrainian version of the questionnaire lists the minimum wage in, respectively, PLN and UAH - hryvnia. and the appropriate times, so that respondents could select the appropriate answer. Some respondents reported income of three-four times the minimum wage.

One way to measure the innovativeness of consumers is to examine their willingness to purchase new products. To this end, the Rogers scale was used, whereby the innovative consumer is a function of the time required to assimilate innovation. Understandably, the consumers surveyed did not accept innovative products at the same pace, hence justifying their division into five groups (Rogers, 2003) by rate of acceptance (Table 1.).

Table 1.: The innovativeness of Polish and Ukrainian consumers on the food market using the Rogers scale $(\%)\left(\chi_{2}=22,9033 ; \mathrm{df}=4, \mathrm{p}=0,0001\right)$

\begin{tabular}{|l|r|r|r|r|r|}
\hline \multicolumn{1}{|c|}{ Specification } & Innovators & \multicolumn{1}{c|}{$\begin{array}{c}\text { Early } \\
\text { Adopters }\end{array}$} & \multicolumn{1}{c|}{$\begin{array}{c}\text { Early } \\
\text { Majority }\end{array}$} & $\begin{array}{c}\text { Late } \\
\text { Majority }\end{array}$ & \multicolumn{1}{c|}{ Laggards } \\
\hline Rogers Model & 2,5 & 13,5 & 34 & 34 & 16 \\
$\begin{array}{l}\text { Polish } \\
\text { consumers }\end{array}$ & 5,9 & 35,3 & 25,9 & 23,5 & 9,4 \\
$\begin{array}{l}\text { Ukrainian } \\
\text { consumers }\end{array}$ & 4,7 & 24,7 & 23,5 & $4,1,1$ & 5,9 \\
\hline
\end{tabular}

Source: the authors, Everett M. Rogers, (2003)

The empirical data collected show that Polish respondents were characterised by a higher level of innovativeness as measured by the pace of acceptance of new products. Among the Polish respondents there were more innovators $(5 \cdot 9 \%)$, adopters $(35.3 \%)$ and early majority $(25.9 \%)$, or those who buy products after they have been tested by others. At 41,2 percent, the greatest share of Ukrainian respondents belonged to the late majority, or consumers who buy new foods only after most of their friends have already acquired and expressed their approval of them. The differences between the Polish and Ukrainian samples are statistically significant. The results of the study population differ from Rogers' theoretical model. In another study, Polish researchers also observed a distribution of different types of consumers that did not match Rogers' categorisation (Gutkowska and Ozimek, 2005). The differences in test results obtained by different authors are probably dictated by the different methodological approaches, which are related mainly to the method of sampling used for the testing. 
The study's participants were asked to identify their three main motivations and barriers, by answering multiple-choice questions. With regard to the motives, most of the Polish respondents pointed to the fact that they like a variety of foods and are interested in new products on the market. $27^{8}\left(81.7^{\%}\right)$ and $246\left({ }_{71} \%\right)$ of the respondents indicated these motives. Caring for one's health was the factor most indicated by the Ukrainian consumers (216 persons - 84.7\%). Figure 1 shows the motives that guide the Polish and Ukrainian respondents when choosing innovative foods. The motives that were least frequently indicated by both the Poles and Ukrainians were those associated with the impact of the external environment, namely the desire to impress and meet the expectations of relatives. The motives identified in the study confirm that today's consumers are paying attention to the health aspects of food, and it is widely known that the awareness of eating high-quality food is one of the elements of a modern lifestyle.

Figure 2.: The motives in consuming innovative foods among Polish and Ukrainian consumers (number of responses)

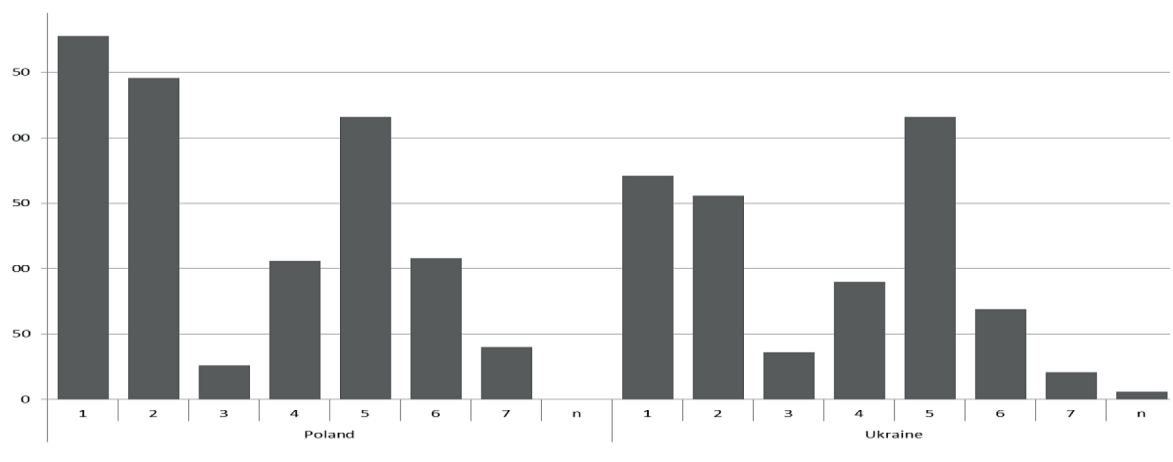

1. I like a varied diet

2. I'm interested in new food

3. I want to impress others

4. I'm interested in nutritional issues
5. I care about my health

6. Intensive promotion of such products

7. Relatives expectations

Source: authors' survey results

As regards the barriers, the highest number of both Polish and Ukrainian consumers-274 and 201, respectively-indicated the high prices of innovative foods. This is clearly the main barrier, not least because the manufacturers of innovative food products often use the strategy of high prices in the product launch phase. Polish consumers also pointed to the poor availability of these products, while Ukrainian consumers named a lack of information as an additional barrier. In addition to product-related factors, marketing communications issues also present hurdles to consumption. The number of indications for specific barriers for Polish and Ukrainian consumers is shown in Figure 3. 
Figure 3.: Barriers to consuming innovative foods among Polish and Ukrainian consumers

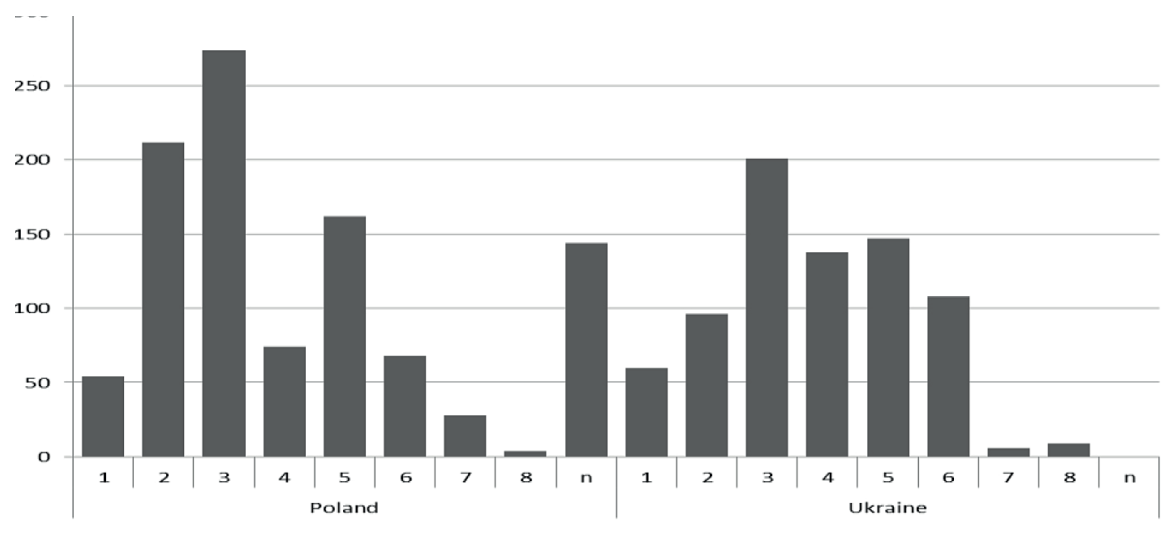

1. Few new products in the market

5. Limited information

2. Limited availability

6. Preference for traditional products

3. High price

7. It does not matter what I eat

4. Experts, doctors do not recommend 8.Other

such food

Source: authors' survey results

Factors determining the purchase of innovative food products were identified, and assessed on a scale of 1 to 5 , with 1 being unimportant and 5 extremely important. The questions were multiple choice, with six factors potentially influencing a purchase: affordable price, strong promotion, easy availability, appearance of packaging, brand and product origin. The answers to the questions are presented in Figure 4 .

Figure 4.: Assessment of factors determining the purchase of innovative food products, 1 unimportant, 5 very important (number of indicators)

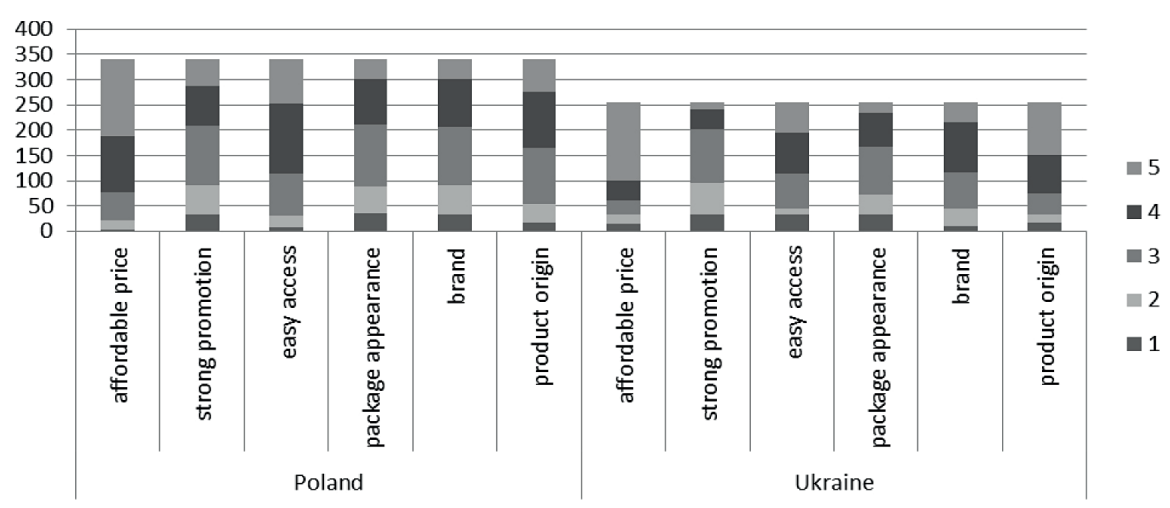

Source: authors' survey results 
Among the Polish consumers, 262 (77 \%) said affordability and $226(67 \%)$ indicated easy access were the most important factors (and hence assigned them a 4 or 5 on the importance scale. Among Ukrainian consumers, affordability (195 respondents $-76 \%$ ) and product origin (180 respondents - $70 \%$ ) were ranked the highest. To analyze the responses to this question, an indicator of the similarity of structures described by the following formula was used:

$$
\omega_{p}=\sum_{i=1}^{k} \min \left(\omega_{1 i} ; \omega_{12}\right)
$$

where $w_{i i}$ are the variants of the answers for Poland, a $w_{2 i}$ are the variants of the answers for Ukraine.

The value measure belongs to the interval $[0,1]$, and the closer the value is to unity, the more similar the structure of the community will be. Based on the results of the study, it was calculated that the structure of the response to the Polish respondents were the most similar to the structure of the responses from the Ukraine in the evaluation of the factor appearance of packaging. In this case, the similarity of the structure was nearly complete, amounting to o.96. The least similar response-the similarity measure was .75 -was observed for product origin. The similarity measure for the remaining factors was: affordable price - 0.77 , strong promotion - 0.82 , easy availability - 0.87 , and brand -0.85 .

\section{RESEARCH IMPLICATIONS}

Research results present certain remarks for managers responsible for introducing new food products to the market. Special attention needs to be drawn to the pricing strategy of these products, as high prices are the main barrier to buying innovative food products. In most cases, the strategy used when introducing innovative products consists of high prices which are lowered as the product gets more popular. The appropriateness of this strategy should be evaluated. The availability of these products should also be considered. Very often, innovative food products are mainly available in big retail chains with limited availability in smaller towns and villages. Traditional trade should also be considered in regards to availability improvements, with innovative products also being introduced to the market through this distribution channel.

\section{CONCLUSIONS}

Introducing innovation is seen as a fundamental factor for companies seeking to boost competitiveness and achieve success on the market. However, for a company to benefit from doing so, the innovation must be accepted and purchased by 
consumers. Only a small percentage of new products are diffused and accepted by consumers today. Whether they are depends to a large extent on innovative consumers appearing with a propensity to purchase innovative products within a short time of their appearing on the market. Rogers' model, which measures the likelihood of consumers to purchase a new product, is widely used to measure consumer innovativeness. The research done for this paper employed the Rogers model to examine how innovative Poles and Ukrainians are as consumers. The results clearly show a distribution different from the Rogers distribution of consumers, as well as differences between the innovation of Polish and Ukrainian consumers. The Polish and Ukrainian consumers also proved somewhat different in terms of the motives and barriers they perceive to purchasing innovative foods. One thing is certain: all of the survey's respondents focus on taking care of their health, which was one of the key motivators. Both groups also indicated that the high prices innovative products command stand in the way of their purchasing them. 


\section{REFERENCES}

Adamowicz Mieczysław, Zachowanie konsumentów w procesach adopcji innowacji na rynku owoców, in: Mieczysław Adamowicz (ed.), Innowacje i innowacyjność w sektorze agrobiznesu, Prace Naukowe 45(1). Warsaw: WULS, (2008): 221-231

Arts Joep W.C., Ruud T. Frambach, Tammo H.A. Bijmolt, Generalizations on consumer innovation adoption: a meta-analysis on drivers of intention and behavior. International Journal of Market Research, 28, 2, (2011)

Earle Mary, Richard Earle, Allan Anderson, Opracowanie produktów spożywczych. Podejście marketingowe. Warsaw: WNT., 2007

Foxall Gordon R., Seema Bhate, Cognitive Style and Personal Involvements Explicators of Innovative Purchasing of 'Healthy' Food Brands. European Journal of Marketing, Vol. 27, No 2, (1993): $5^{-16}$

Goldsmith Ronald E., Charles F., Hofacker, Measuring consumerinnovativeness. Journal of Academy Of Marketing Science, 19(3), (1991): 209-221

Roland E. Goldsmith, Using the domain specific innovativeness scale to identify innovative internet consumers. Interent Research, 11 (2), (2001): 14.9-158

Górska-Warsewicz Hanna, Innowacje produktowe w opinii konsumentów. Przemysł Spożywczy, 3, 2003

Gutkowska Krystyna, Irena Ozimek, Wybrane aspektyzachowańkonsumentówna rynku żywności - kryteria zróżnicowania. Warsaw: WULS, 2005

Jeżewska-Zychowicz Marzena, Zachowania żywieniowe i ich uwarunkowania. Warsaw: WULS, 2007

Jeżewska-Zychowicz Marzena, Ocena innowacyjności konsumentów na rynku żywnościz uwzględnieniem opakowań produktów żywnościowych [in: ] Mieczysław Adamowicz (ed.) Innowacje i innowacyjność w sektorze agrobiznesu. Warsaw: WULS, (2008): 273-280

Jeżewska-Zychowicz Marzena, Uwarunkowania akceptacji nowych produktów żywnościowych, in: Andrzej Kropiwiec, Akceptacja nowych produktów żywnościowych ijejuwarunkowania, Warsaw: WULS, (2012)

Jeżewska-Zychowicz Marzena, Uwarunkowania akceptacji konsumenckiej innowacyjnych produktów żywnościowych. Food. Science. Technology. Quality, 6 (97), (2014): $5^{-17}$

Klincewicz Krzysztof, Dyfuzja innowacji. Jak odnieść sukces wkomercjalizacji innowacyjnych produktówi ustug. Warsaw: University of Warsaw, 2011

Kowalczuk Iwona, Innowacyjność konsumentów na rynku żywności. Handel Wewnętrzny, 6 , (2010): 27-33

Kowalczuk Iwona, Innowacyjna żywność w opinii konsumentów i producentów. Warsaw: WULS, 2011

Kraszewska, Magdalena, Determinanty akceptacji innowacji przez konsumentów na rynku owoców i przetworów owocowych- przeglšd literatury, in: M.Adamowicz (ed.) Konsumenci a innowacje na rynku owoców, Warsaw: WULS, (2011): $74^{-8} 5$ 
Labay, Duncan.G., Thomas C. Kinnear, T.G., Exploring the consumer decision process in the adoption of solar energy systems. Journal of Consumer Research, 8, (1981): 271-276

Laskowski Wacław, Górska-Warsewicz Hanna, Czynniki ekonomiczne determinujšce wybory konsumenckie, in: Gęstość odżywcza spożywanych racji pokarmowych w Polsce. Próba oszacowania i oceny wptywu statusu ekonomicznego. Warsaw: Laskowski, 2014

Lowe Ben, Frank Alpert, Forecasting consumer perception of innovativeness. Technovation, 45-4,6, $(2015): 1-14$

Pliner, Patricia, Karen Hobden, Development of a scale to measure the trait food neophobia. Appetite, 19(2), (1992): 105-120

Ronteltap Amber, Hans van Trijp, Reit Renes, Lynn Frewer, Consumer acceptance of technologybased food innovations: Lessons for the future of nutrigenomic. Appetite, 49 (1), (2007): 1-17

Steenkamp Jan-Benedict E.M., Frenkel ter Hofstede, Michel Wedel, A cross-national investigation into the individual and national cultural antecedents of consumer innovativness. Journal of Marketing, Vol 63, No 2, (1999): 55-63

Tuorilla Hely, Läahtenmaki Liisa, Pohjalainen Leena, Lotti, Leila, Food neophobia among the Finns and related responses to familiar and unfamiliarfoods. Food Quality and Preference, 12(1), (2001): 29-37 